\title{
Function, clinical application, and strategies of Pre-mRNA splicing in cancer
}

\author{
Cuixia $\mathrm{Di}^{1,2,3} \cdot$ Syafrizayanti ${ }^{4,5} \cdot$ Qianjing Zhang ${ }^{1,2,3} \cdot$ Yuhong Chen $^{1,2,3} \cdot$ Yupei Wang ${ }^{1,2,3} \cdot$ Xuetian Zhang ${ }^{1,2,3} \cdot$ \\ Yang Liu ${ }^{1,2} \cdot$ Chao Sun ${ }^{1,2} \cdot$ Hong Zhang ${ }^{1,2} \cdot$ Jörg D. Hoheisel ${ }^{4}$
}

Received: 13 August 2018 / Revised: 9 October 2018 / Accepted: 23 October 2018

(c) The Author(s) 2018. This article is published with open access

\begin{abstract}
Pre-mRNA splicing is a fundamental process that plays a considerable role in generating protein diversity. Pre-mRNA splicing is also the key to the pathology of numerous diseases, especially cancers. In this review, we discuss how aberrant splicing isoforms precisely regulate three basic functional aspects in cancer: proliferation, metastasis and apoptosis. Importantly, clinical function of aberrant splicing isoforms is also discussed, in particular concerning drug resistance and radiosensitivity. Furthermore, this review discusses emerging strategies how to modulate pathologic aberrant splicing isoforms, which are attractive, novel therapeutic agents in cancer. Last we outline current and future directions of isoforms diagnostic methodologies reported so far in cancer. Thus, it is highlighting significance of aberrant splicing isoforms as markers for cancer and as targets for cancer therapy.
\end{abstract}

\section{Facts}

- Differential splicing is an important factor of expanding and diversifying the molecular function portfolio of human cells.

\footnotetext{
Edited by: E. Baehrecke

These authors contributed equally: H. Zhang, J. D. Hoheisel.

Hong Zhang

zhang.h@impcas.ac.cn

$\square$ Jörg D. Hoheisel

j.hoheisel@dkfz.de

1 Department of Radiation Medicine, Institute of Modern Physics, Chinese Academy of Sciences, 730000 Lanzhou, China

2 Key Laboratory of Heavy Ion Radiation Biology and Medicine of Chinese Academy of Sciences, 730000 Lanzhou, China

3 College of Life Sciences, University of Chinese Academy of Sciences, Beijing, China

4 Division of Functional Genome Analysis, German Cancer Research Center (DKFZ), Im Neuenheimer Feld 580, 69120 Heidelberg, Germany

5 Department of Chemistry, Faculty of Mathematics and Natural Sciences, Andalas University, Kampus Limau Manis, Padang, Indonesia
}

- Cancer-associated splicing events have been found to be involved in human cancer initiation and tumour development.

- Splice differences can be exploited as markers for more accurate diagnosis as well as improved prognosis and monitoring of treatment response in patients with cancer.

- Technology has facilitated the investigation of splicing changes; rather than getting isolated results from distinct studies, a more global picture of the role of alternative RNA splicing in human cancer is beginning to emerge.

\section{Open Questions}

- Do personal splice variations or particular combinations thereof exist in individual cancer patients?

- What are the strategies modulate target gene splicing and thus inhibit tumour growth of human cancer?

- Can protein isoforms that results from alternative RNA splicing in individual patients with cancer provide treatment options as part of a precision medicine approach?

- Could splice variations be better reversed by applying new genome editing processes, such as CRISPR-Cas, or would proteomic procedures, such as provision of specific antibodies against the tumour-specific protein 
isoform do a better and/or technically superior job in clinical application?

\section{Introduction}

Most human genes harbour introns that are removed during pre-mRNA splicing [1]. Next-generation sequencing results suggest that more than $90 \%$ of human genes that encode proteins undergo pre-mRNA splicing [2]. Pre-mRNA splicing is a common post-transcriptional process used by eukaryotic organisms to generate multiple transcript isoforms from a single gene. This process expands substantially the variety of encoded proteins, thus providing another means of functional regulation [3]. Structural differences that result from splice differences are likely to translate to functional variation. Regulation of splicing could therefore affect cellular fate and function in cancer [4].

Pre-mRNA splicing has been discovered to be critical for genesis and development of different types of cancer $[5,6]$. An increasing body of data points to a role of premRNA splicing in controlling the switch between cell life and death in cancer (Fig. 1). The balance between noncancerous isoform and cancerous isoform is an important contributor to cancer genesis. To date, there are particularly two approaches of interfering with the RNA splicing process. Hence the aim of this review is to discuss how alternative splicing precisely regulates proliferation, metastasis, apoptosis, drug resistance and radiosensitivity in cancer. Additionally, we discuss emerging novel strategies how to modulate pathologic splicing isoforms in cancer. For any pharmacological regulation, this would create the opportunity to produce a drug that may affect the tumour in a really targeted manner. Furthermore, we outline current and future directions of methodologies

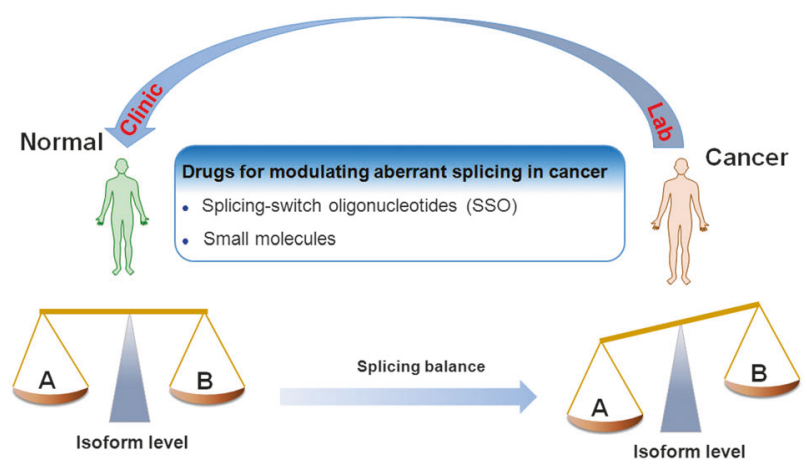

Fig. 1 The role of alternative RNA splicing in cancer. The balance between noncancerous isoform (a) and cancerous isoform (b) is an important contributor to cancer genesis. To date, there are particularly two approaches of interfering with the RNA splicing process: the use of SSO and application of appropriately active small molecules reported so far for measuring aberrant splicing isoforms. Technological developments could create a knowledge basis rather quickly, which is sufficiently large and solid enough to identify aberrant splicing isoforms as markers for cancer. Thus this review elaborated from different angles will be helpful to better understand the significance of alternative splicing as markers for cancer and targets for future therapeutic strategies.

\section{Types of AS and its regulation}

While many exons are constitutively spliced together, alternative splicing (AS) is a process during which specific exons are selectively included or excluded [7]. AS is of great physiological relevance as it enables the production of multiple protein isoforms from a single pre-mRNA molecule by the combinatorial use of splice sites. This gives rise to a variety of proteins that might show similar, different or even opposing functions. In addition to protein diversity, AS can also lead to reduced translation of mRNAs through introduction of a premature stop codon leading to sequestration and degradation of transcripts in the nucleus; these exons are often referred to as poison exons [8, 9]. There are different types of alternative splicing events, which generate mRNAs encoding proteins (Fig. 2). The most common type

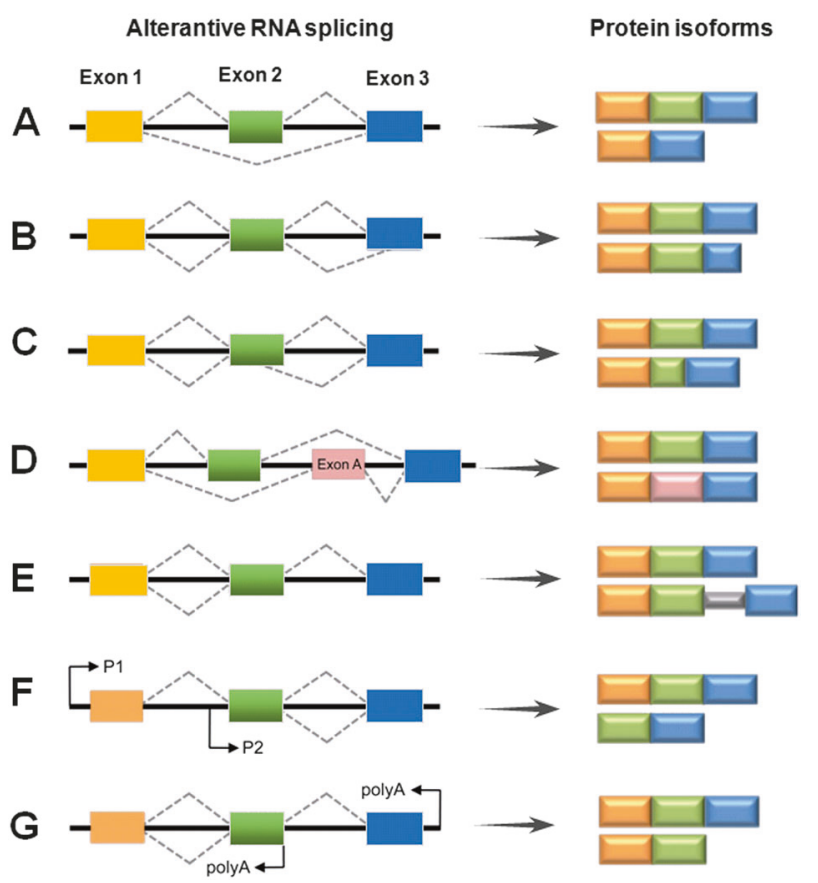

Fig. 2 Schematic representation of different types of RNA splicing. The dotted grey lines indicate the alternative splicing processes: a exon skipping; b, c alternative $3^{\prime}$ - and $5^{\prime}$-SS; $\mathbf{d}$ mutually exclusive exons; $\mathbf{e}$ intron retention; $\mathbf{f}$ usage of alternative promoters; $\mathbf{g}$ alternative polyadenylation. $\mathrm{P}$ promoter, polyA site of polyadenylation 
of AS, accounting for nearly $40 \%$ of events in higher eukaryotes is exon skipping [10], in which a cassette exon is spliced out of the transcript together with its flanking introns (Fig. 2a). One or several exons are not present in the final mRNA. Second and third, there are alternatives in the selection of either $3^{\prime}$ - or $5^{\prime}$-splice sites (Fig. 2b, c). The fourth type of splice variation is mutually exclusive exons (Fig. 2d), which represents a rare subtype [11]. The fifth type of splice variation is intron retention (Fig. 2e), in which an intron remains in the mature mRNA transcript rather than being removed during maturation. RNA sequencing and other data demonstrate that intron retention is a common mechanism of tumour-suppressor inactivation, is widespread across cancer entities and contributes to their transcriptional diversity [12]. There are also other types of AS, include use of alternative promoters, and unusual polyadenylation (Fig. 2f, g). Recently, it was shown that exon transcripts in pre-mRNAs might also be non-linearly reverse-spliced into a circular RNA [13].

The chemistry of the splicing reaction is mediated by the "spliceosome", an RNA-based machine containing five small nuclear ribonucleoproteins snRNAs and numerous associated proteins [14]. Splicing regulation involves both cis-acting splicing-regulatory elements (SREs) and trans-acting splicing factors [15]. SREs act as either enhancers or silencers of splicing and can exist in either exons or introns. Historically these elements are named as exonic splicing enhancers or silencers, and intronic splicing silencers or enhancers. By recruiting trans-acting splicing factors, cis-acting splicing-regulatory elements either activate or inhibit the usage of adjacent splice sites, thus to specifically control alternative splicing [16]. Changes in the activity and composition of general or specific splicing factors modify the selection of splice sites [17]. Recent reports showed that DNA methylation in either cis-acting splicing-regulatory elements or trans-acting splicing factors is associated with various cancers, such as prostate [18], breast, lung cancer [19] and et al. Whilst extensive studies reported that single-nucleotide polymorphisms in these sites could modulate the risks of cancer development and outcome [20].

\section{Function of aberrant splicing isoforms in cancer}

For a number of relevant genes, RNA splicing determines isoforms with distinct and even opposing functions (Table 1). Some RNA splicing isoforms are listed here to show how precisely they regulate proliferation, metastasis, and apoptosis in cancer. Various splicing events are not separated, but co-ordinated in cancer cell.

\section{Proliferation}

Numerous cases of splicing isoforms that drive or promote cancer progression have been identified over the years. Some isoforms are selected to show how they exactly regulate proliferation in cancer (Table 1). Cyclin D1b, an isoform of cyclin D1, is originated from intron-4 retention. Clinical evidence demonstrated that cyclin D1b is induced in lymphoma, oesophageal, breast, lung and prostate cancer [21]. Furthermore, cyclin D1b expression is associated with tumour progression and therapeutic failure in breast [22] and prostate cancer [23], and is an independent predictor of poor prognosis and survival in small-cell lung cancer [24]. Thus these findings suggest that cyclin D1b represents an oncogenic isoform of cyclin D1. Also, ras-association domain family 5 isoform A (RASSF5A) originated from different promoter usage and was considered to be a candidate tumour suppressor that was epigenetically inactivated in oesophageal squamous cell carcinoma [25]. Interestingly, spleen tyrosine kinase (Syk) is a candidate tumour suppressor that is highly expressed in mammary epithelial cells. While the aberrant expression of $\operatorname{Syk}(\mathrm{S})$ occurs frequently in primary breast tumours but never in matched normal mammary tissues, suggesting a contribution of $\operatorname{Syk}(\mathrm{S})$ to mammary tumour progression [26]. Recently, another study identified an isoform of wilms' tumour 1 (WT1)-produced by exon skipping, leading to cell proliferation, and might be involved in the development and progression of breast cancer [27]. Thereby, differential splicing is an important factor of expanding and diversifying the molecular function portfolio of proliferation in human cancer cells.

\section{Metastasis}

Some RNA splicing isoforms are listed here to show how precisely they regulate metastasis (Table 1). One of the interesting examples is CD44. Its pre-mRNA harbours 10 adjacent exons that are included in a combinatorial manner to give rise to multiple isoforms. Switch from CD44v to CD44 standard (CD44s), leading to suppression of lung colonisation of metastatic cancer [28]. Among CD44v isoforms, CD44v6 seems has been extensively studied in different types of cancer including colon, ovarian, and head and neck [29]. CD44v6 is more specifically expressed in cancer tissues, but CD44 has an ubiquitously expression pattern [30]. CD44v6 was also found to be a marker of constitutive and reprogrammed cancer stem cells driving colon cancer metastasis [31]. Therefore, CD44v6 has attracted more interest than CD44 in terms of tumour markers, diagnosis, and treatment. In line with a potential therapeutic application, antibodies to CD44v6 have shown 
Table 1 Aberrant splicing isoforms in cancer and its clinical application

\begin{tabular}{|c|c|c|c|c|c|}
\hline & $\begin{array}{l}\text { Isoform A } \\
\text { Isoform B }\end{array}$ & Function & Cancer type & Splicing type & Refs \\
\hline \multirow[t]{8}{*}{ Proliferation } & cyclin D1 & Tumour suppressor gene & Prostate tumours & Intron retention & {$[21]$} \\
\hline & cyclin D1b & $\begin{array}{l}\text { Associate with } \\
\text { progression }\end{array}$ & & & \\
\hline & Syk & Tumour suppressor & Breast tumours & Exon skipping & {$[26]$} \\
\hline & $\operatorname{Syk}(S)$ & $\begin{array}{l}\text { Mammary tumour } \\
\text { progression }\end{array}$ & & & \\
\hline & RASSF5 & Tumourigenesis & Oesophageal & Promoter usage & {$[25]$} \\
\hline & RASSF5A & Tumour suppressor & cancer & & \\
\hline & WT1 & Proliferation & Breast cancer & Exon skipping & {$[27,100]$} \\
\hline & WT1iso & $\begin{array}{l}\text { Development \& } \\
\text { progression }\end{array}$ & & & \\
\hline \multirow[t]{8}{*}{ Metastasis } & CD44 & Drive metastasis & Breast cancer & Addition of & {$[30]$} \\
\hline & CD44V6 & Pro-metastatic molecule & & amino acids & \\
\hline & CrkII & Migration & Glioblastoma & Exon skipping & [101] \\
\hline & CrkI & Promote cell migration & & & \\
\hline & KLF6 & Tumour suppressor gene & Lung cancer & $5^{\prime}-\mathrm{SS}$ & {$[34]$} \\
\hline & KLF6-SV1 & $\begin{array}{l}\text { Driver of tumour } \\
\text { metastasis }\end{array}$ & & & \\
\hline & VEGFA & Metastasis & Sarcoma & Exon 8 & {$[35]$} \\
\hline & VEGFA iso & $\begin{array}{l}\text { Advantage for } \\
\text { metastasis }\end{array}$ & & & \\
\hline \multirow[t]{8}{*}{ Apoptosis } & BCL-Xs & Pro-apoptosis & Many cancer & $5^{\prime}-\mathrm{SS}$ & [75] \\
\hline & BCL-XL & Anti-apoptosis & types & & \\
\hline & $\mathrm{nCLu}$ & Pro-apoptotic & Many cancer & Frame shift & {$[41]$} \\
\hline & sCLu & Pro-survival & types & & \\
\hline & ELF2A & Pro-apoptosis & Cancer cell lines & $5^{\prime}-\mathrm{SS}$ & {$[42]$} \\
\hline & ELF2B & Anti-apoptosis & & & \\
\hline & RIP3 & Pro-apoptosis & Colon \& lung & Intron retention & {$[43]$} \\
\hline & $\mathrm{RIP} 3 \gamma$ & Anti-apoptosis & cancer & & \\
\hline \multirow[t]{8}{*}{ Drug resistance } & $\mathrm{AR}$ & Chemosensitivity & Prostate cancer & Exon skipping & {$[70]$} \\
\hline & AR-v7 & Chemoresistance & & & \\
\hline & BRCA1 & Repair of DNA break & Breast cancer & Exon skipping & [49] \\
\hline & $\mathrm{BRCA} 1 \Delta 11$ & Chemoresistance & & & \\
\hline & c-FLIP(L) & Anti-apoptosis & Pancreatic cancer & Truncated C- & {$[50]$} \\
\hline & c-FLIP(S) & Drug resistance & & terminus & \\
\hline & Survivin & Anti-apoptosis & Neoplastc cells & Intron retention & {$[48]$} \\
\hline & Survivin 3B & $\begin{array}{l}\text { Promote } \\
\text { chemoresistance }\end{array}$ & & & \\
\hline \multirow[t]{8}{*}{ Radiotherapy } & sCLu & Genomic instability & Breast cancer & $5^{\prime}-\mathrm{SS}$ & {$[53]$} \\
\hline & $\mathrm{nCLu}$ & Pro-death factor & cells & & \\
\hline & Mcl-1L & Anti-apoptotic & OSCC & Exon skipping & {$[54]$} \\
\hline & Mcl-1S & Pro-apoptotic & & & \\
\hline & NPM1 & Radioresistance & Cervical cancer & Intron retention & {$[55]$} \\
\hline & NPM2 & Radiosensitivity & & & \\
\hline & Tap73 & Pro-apoptosis & Cervical cancer & Exon skipping & {$[60]$} \\
\hline & $\Delta \mathrm{Np} 73$ & Anti-apoptosis & & & \\
\hline
\end{tabular}


promise in human head and neck cancer in a clinical trial [32]. Additionally, another isoforms also exhibited similar properties like CD44. The human $\mathrm{Crk}$ gene, for instance, was translated into CrkI and CrkII. CrkII was detected in both normal brain and glioblastoma tissues, whereas CrkI levels were quite low in normal brain but up-regulated in glioblastoma tissues [33]. Additionally, KLF6 is tumour suppressor gene, but its isoform has different role. Hatami et al. reported that the Klf6-sv1 isoform was a key driver of metastasis and could act as a potential therapeutic target for invasive breast cancer [34]. Vascular endothelial growth factor A (VEGFA) was a potent regulator that contributed to tumour growth and metastasis, while the isoform expression could be used to predict treatment outcome with bevacizumabin in sarcoma [35]. A frequent observation is that high expression of the $\alpha 6$ integrin subunit is a biomarker for breast and other cancer stem cells, but the $\alpha 6 \mathrm{~B} \beta 1$ integrin isoform drives cancer stem cells function in triple-negative breast cancer and promotes tumour initiation [36]. Chang et al. [37] reported that a laminin 511 matrix functions as the ligand for the $\alpha 6 \mathrm{~B} \beta 1$ integrin to sustain breast cancer stem cells. Thus, these suggest that the aberrant splicing isoforms may be therapeutic targets.

\section{Apoptosis}

An increasing body of data points to a role of RNA splicing in controlling the switch between cell life and death in cancer [38]. One of the earliest oncogenic AS events described is the apoptosis gene Bcl-x [39], which generates two splicing isoforms, a shortform (Bcl-xS) with proapoptotic properties and a long form (Bcl-xL) with an antiapoptotic effect. A wide range of tumours, including breast, colon, and lung, exhibit high levels of $\mathrm{Bcl}-\mathrm{xL}$, resulting in reduced apoptosis potential and providing the tumour with elevated cell survival [29, 40]. Another isoforms also exhibited similar properties like Bcl-x. Clusterin (CLU) was implicated in various cell functions involved in the tumorigenesis of various malignancies, but the isoform of the CLU protein was shown to act pro-apoptotic [41]. Guan et al. [42] reported that conserved ELF2 isoforms, ELF2A and ELF2B, arising from alternative promoter usage, exerted opposing affects on target gene expression. Interestingly, ELF2A activated cancer cell proliferation, while ELF2B induced cancer cell apoptosis. Yang et al. also showed that receptor-interacting protein 3 (Rip3) was an apoptosisinducing member, but the Rip $3 \gamma$ isoform down-regulated Rip3-mediated apoptosis in colon and lung cancers [43]. These findings suggest that modulating splicing might redirect the fate of cancer cells.

\section{Clinical application of alternative splicing in cancer}

\section{Drug resistance}

RNA splicing might be an important determinant of clinical response and offered a therapeutic target for enhancing drug sensitivity in cancer (Table 1). One interesting gene that determines drug resistance is androgen receptor (AR) (Fig. 3). The full-length AR (AR-FL) is composed of an Nterminal domain, a central DNA-binding domain, a hinge region, and a C-terminal ligand-binding domain (LBD) (Fig. 3a). Because of insertions of cryptic exons downstream of the DNA-binding domain, AR-v7 transcripts lack the reading frame for the LBD. The LBD is the part of the AR molecule to which testosterone bind, as well as being the target of all antiandrogens including bicalutamide and enzalutamide [44]. This Fig. 3b highlights the AR activation axis, with conversion of testosterone to dihydrotestosterone (DHT) by the $5 \alpha$-reductase enzyme, and subsequent AR activation, dimerisation, nuclear translocation and activation of transcriptional activation of target genes. AR-v7 is characterised by loss of the LBD with preservation of the DNA-binding domain, often resulting in testosteroneindependent activation of the AR axis, a process known as constitutive activation (Fig. 3c). Multiple clinical correlative studies have suggested that AR-v7 is involved in the pathogenesis of disease progression, and poor outcomes from the use of abiraterone and enzalutamide in castrationresistant prostate cancer (CRPC) patients [45, 46]. AR-v7 functions as constitutively active transcription factor, thereby promoting resistance to AR-targeted therapies. Just then Seitz et al. also showed that testing of Ar-v7 mRNA levels in whole blood was a simple and promising approach to predict poor treatment outcome in CRPC patients receiving abiraterone or enzalutamide. AR-v7 has the potential to revolutionise how you make treatment decisions for patients with metastatic CRPC. Recently, therapies preventing expression of AR-v7 in CRPC were developed [47]. The splicing of AR isoforms AR-v7 is regulated by a single polyadenylation signal in AR intron 3. Blocking this signal with morpholino technology or silencing of the polyadenylation factor CPSF1 caused a splice switch that inhibited expression of AR isoforms and blocked androgenindependent growth of CRPC cells (Fig. 3c).

There were also another isoforms exhibited similar properties like AR-v7. Survivin-3b, an alternative splice isoform of survivin, increased the resistance of neoplastic cells to various chemotherapeutics [48]. Human BRCA1 played an important role in the repair of DNA-damage response, while BRCA1- $\Delta 11$ harbouring mutations in exon 11 of BRCA1 promoted chemoresistance to cisplatin [49]. 

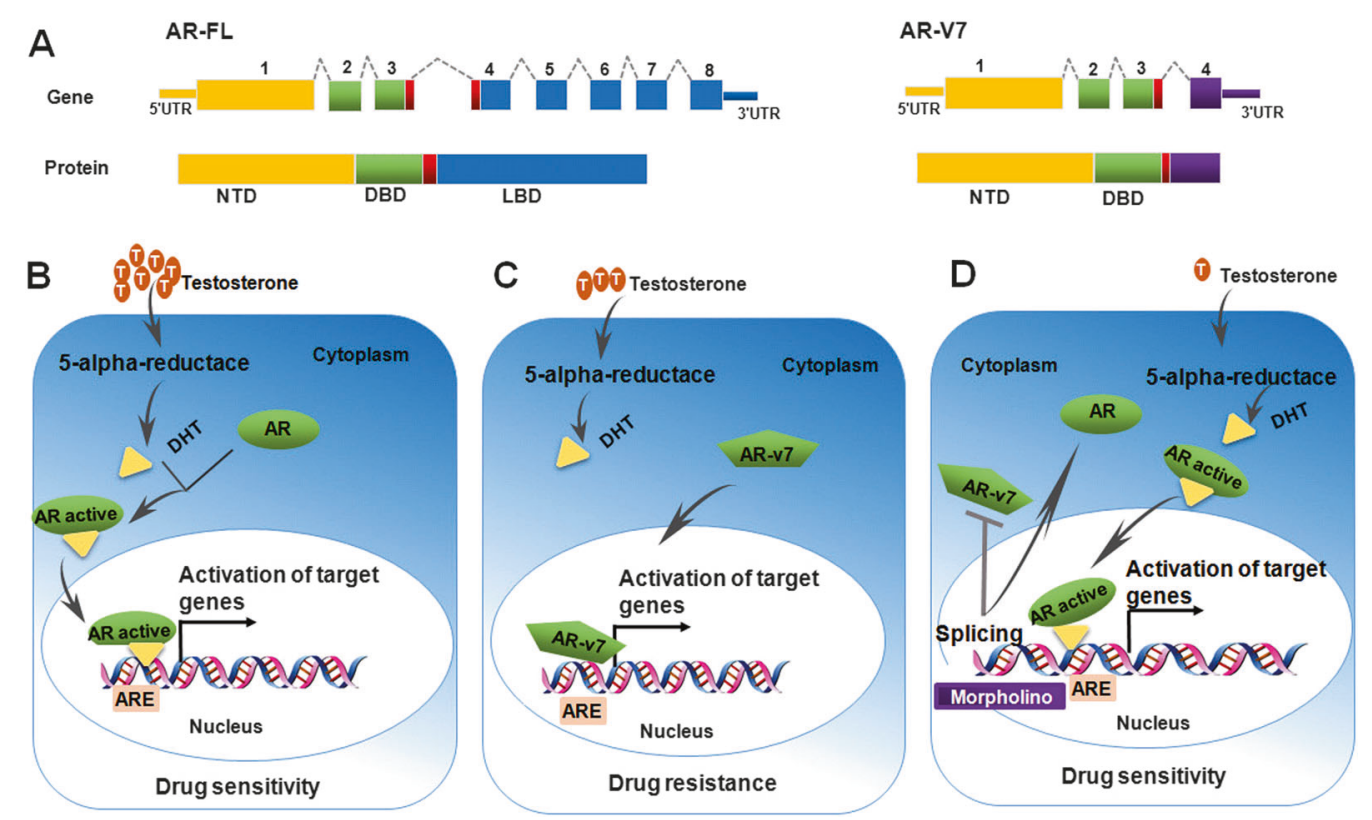

Fig. 3 Schematic representation of AR-v7 mechanism of action in chemoresistance. a AR-FL is composed of an N-terminal domain (NTD), a central DNA-binding domain (DBD), a hinge region (red box), and a C-terminal ligand-binding domain (LBD). AR-v7 transcripts lack the reading frame for the LBD. b it highlights the AR activation axis, with conversion of testosterone to dihydrotestosterone (DHT) by the $5 \alpha$-reductase enzyme, and subsequent AR activation,

Additionally, Haag et al. reported that both the long and the short isoform of the anti-apoptotic protein c-FLIP were critical regulators of apoptosis in pancreatic carcinoma cells and suppressed by chemotherapeutics [50]. A pre-treatment with drugs down-regulated c-FLIP isoform and rendered cells sensitive to chemotherapeutics [51].

\section{Radiosensitivity}

The success of treating cancer patients by radiotherapy largely depends on tumour radiosensitivity. Several molecular factors that determine the sensitivity of tumour cells to ionising radiation showed alternative transcription initiation as a response to irradiation and have been identified during the last couple of years (Table 1). Through RNA-sequencing of normal and chemoradiation-resistant colon cancer cells, it was found that exon skipping was significantly increased in chemoradiation-resistant colon cancer cells [52]. Additionally, sCLU played a key role in pro-survival; the nCLU isoform took part in apoptosis in cancer treated with leptomycin B and irradiation [53]. A recent study demonstrated that the protein isoform Mcl-1L had an important role in survival and radioresistance of oral cancer patients [54]. An NPM2 isoform was able to increase cell survival after irradiation in cervical cancer cells [55]. dimerisation, nuclear translocation and activation of transcriptional activation of target genes expression. c AR-v7 is characterised by loss of the LBD, often resulting in testosterone-independent activation of target genes expression. d morpholino technology caused a splice switch that inhibited expression of AR-v7 and blocked testosterone -independent growth of CRPC cells

One interesting molecular factor that determines the sensitivity of tumour cells to ionising radiation is $\mathrm{p} 73$ (Fig. 4). The p73 transcription factors are present in two forms, the full length Tap73 and the N-terminally truncated $\Delta \mathrm{Np} 73$. High expression levels of $\Delta \mathrm{Np} 73$ have been shown to strongly correlate with poor survival of cancer patients and $\Delta \mathrm{Np} 73$ positive tumours show a reduced response to irradiation [56]. Liu et al. [57] suggested that p73a is an important determinant of cellular radiosensitivity in the p53-impaired cervical cancer cells, whereas up-regulation of $\Delta \mathrm{Np} 73$ in cervical cancers was detected mainly in radioresistant cases. Our findings have been reported that there is a differential $\Delta \mathrm{Np} 73$ expression in response to different LET radiations, and downregulated $\Delta \mathrm{Np} 73$ expression might play a critical role in sensitivity of tumour cells [58]. Finally, similar findings have been reported the anti-apoptotic $\Delta \mathrm{Np} 73$ decreased in colon cancer cell lines (KM12C) exposed to $\gamma$-irradiation [59]. Our further research demonstrated that the ratio of TAp73/ $\mathrm{Np} 73$ could be considered a potential molecular switch, regulating $\mathrm{Bax} / \mathrm{Bcl}-2$ ratio, and preventing cytochrome $\mathrm{c}$ release and caspase activation, and enabling sensitisation of cancer cells to high linear energy transfer carbon beams [60, 61] (Fig. 4). Thus these findings suggested that $\mathrm{p} 73$ splicing was related to the radiosensitivity of cancer cells and may play an important role in the regulation of cellular radiosensitivity. 


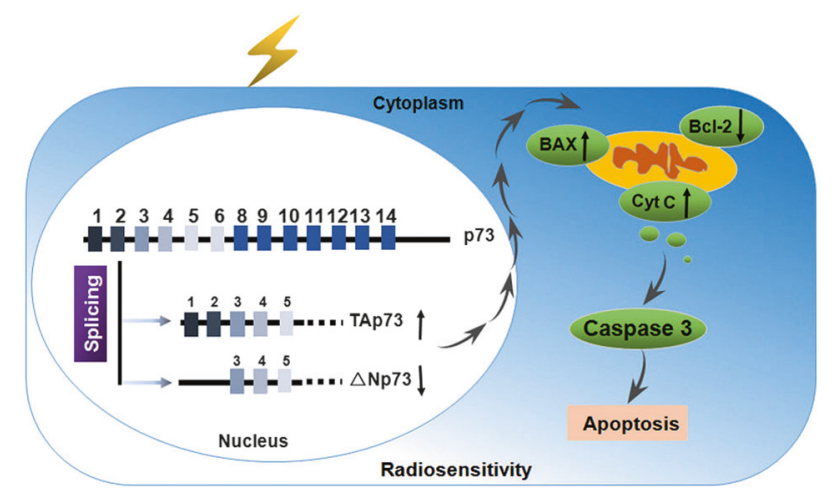

Fig. 4 Schematic representation of p73 mechanism of action in radiosensitivity. The ratio of TAp73/ $\Delta \mathrm{Np} 73$ could be considered a potential molecular switch, regulating $\mathrm{Bax} / \mathrm{Bcl}-2$ ratio, and preventing cytochrome $c$ release and caspase activation, and enabling sensitisation of cancer cells to radiation

\section{Other therapies}

Also for other potential therapeutic options, splice variations have been found to be relevant. Isoform Claudins 18.2 (CLDN18.2) was targeted by the therapeutic antibody IMAB362, which was in advanced clinical phase II testing in gastric cancer patients [62]. Also, macrophage PI 3kinase $\gamma(\mathrm{PI} 3 \mathrm{~K} \gamma)$ controlled a critical switch between immune stimulation and suppression during inflammation and cancer [63]. Targeting PI3K $\gamma$ with a selective inhibitor, which is currently evaluated in a clinical trial (NCT02637531), could overcome resistance to immune checkpoint blockade in patients and promote cytotoxic tumour regression without targeting cancer cells directly [64]. Also the safety and pharmacokinetics of the PI3K $\gamma$ inhibitor IPI549 is being explored, alone and in combination with an antibody against programmed cell death 1 protein [65].

\section{Options modulating RNA splicing in cancer}

\section{SSOs as drugs for regulating RNA splicing in cancer}

The use of RNA splicing modulators is an attractive option for establishing novel therapeutic cancer drugs [29]. To date, splicing-switch oligonucleotides (SSOs) were used as a means of drugs to modulate RNA splicing in cancer. SSOs are short, synthetic, antisense, modified nucleic acids and designed to base-pair and create a steric block to the binding of splicing factors to the pre-mRNA [66]. In this way, SSO base-pairing to a target RNA alters the recognition of splice sites by the spliceosome, which leads to an alteration of normal splicing of the targeted transcript. As shown in Fig. 5, SSOs can target and block trans-acting splicing factors that would change exon splicing and generate a new

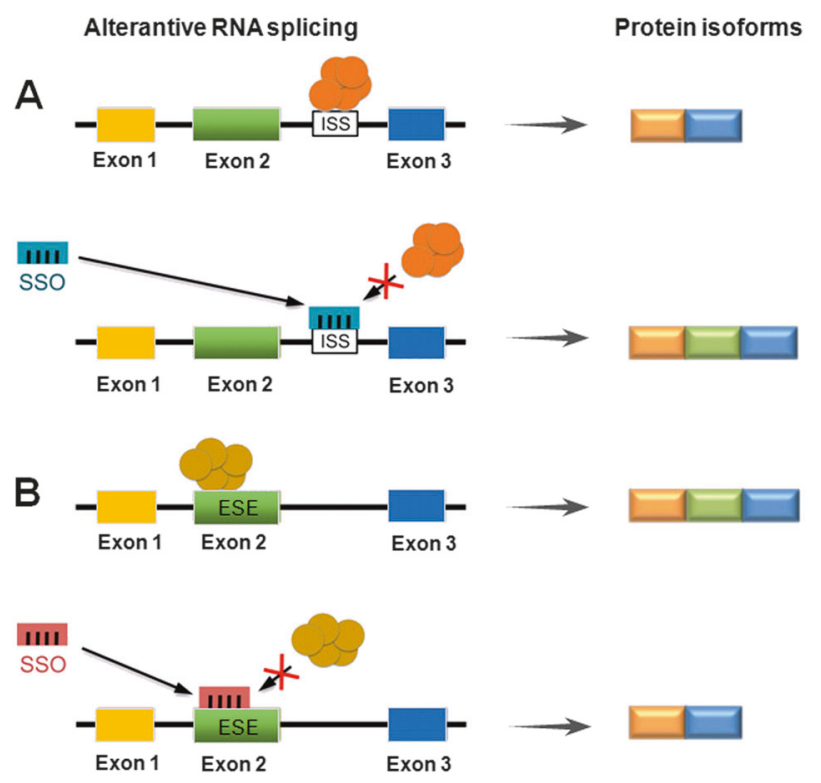

Fig. 5 Splicing-switch oligonucleotides (SSOs) as a means to modulate RNA splicing. a An SSO that binds to an intronic splicing silencer (ISS) prevents binding of a negative splicing factor (orange), leading to exon inclusion. b An SSO that binds to an exonic splicing enhancer (ESE) blocks the binding of the stimulatory splicing factor (mustard), resulting in exon skipping

alternative protein isoform. Importantly, nucleotides of an SSO are chemically modified so that the RNA-cleaving enzyme RNase $\mathrm{H}$ is not recruited to degrade the premRNA-SSO complex [67]. The modifications to the SSO have also been crucial to stabilise the SSO in vivo and improve cellular uptake and release as well as binding affinity [68]. SSOs were first described for the correction of aberrant splicing in human $\beta$-globin pre-mRNAs [69]. During the past 10 years, antisense oligonucleotidemediated exon skipping and splice modulation have proven to be powerful tools for correction of mRNA splicing in genetic diseases. In 2016, the US Food and Drug Administration-approved Exondys 51 (eteplirsen) and Spinraza (nusinersen), the first exon skipping and exon inclusion drugs, to treat patients with Duchenne muscular dystrophy (DMD) and spinal muscular atrophy (SMA), respectively $[70,71]$. The success of trials has also inspired therapeutic applications of SSOs in cancer (Table 2). The $B c l-x$ gene is alternatively spliced, expressing anti-apoptotic $\mathrm{Bcl}-\mathrm{xL}$ and pro-apoptotic Bcl-xS. Bcl-xL expression is upregulated in many cancers and considered a general mechanism by which cancer cells evade apoptosis. Mercatante et al. reported that Bcl-x SSOs shifted splicing from $\mathrm{Bcl}-\mathrm{xL}$ to $\mathrm{Bcl}-\mathrm{xS}$ in prostate and breast cancer cells in vitro. They also found that Bcl-xS protein induced by the SSOs sensitised the cancer cells to treatment with radiation and chemotherapeutic drugs [72]. In other studies, the same group demonstrated that Bcl-x SSOs delivered by lipid 
Table 2 SSOs as drugs for modulating RNA splicing in cancer

\begin{tabular}{llll}
\hline Target & Splicing events & Short description & Refs \\
\hline ATM & Intron 28 inclusion & Susceptibility to radiation in HEK293 cell lines & {$[102]$} \\
Bcl-x & Exon 2 skipping & Induction of apoptosis in human glioma cell lines & {$[75]$} \\
BRCA1 & Exon 11 skipping & Enhancing the effect of PARP inhibitors in breast cancer & {$[103]$} \\
HER2 & Exon 15 skipping & Induction of apoptosis in breast cancer cells & {$[104]$} \\
HER4 & Exon 26 skipping & Decrease growth of breast cancer cells & {$[105]$} \\
MDM2 & Exon 11 skipping & Susceptibility to DNA damage in breast cancer cells & {$[106]$} \\
MDM4 & Exon 6 skipping & Inhibite melanoma growth & {$[107]$} \\
PKM & Exon 10 inclusion & Susceptibility to chemotherapy in pancreatic cancer cells & {$[108]$} \\
STAT3 & Alternative 3' SS & Induction of apoptosis in breast cancer cells & {$[109]$} \\
WT1 & Exon 5 inclusion & Kill HL60 leukaemia cells & {$[110]$} \\
\hline
\end{tabular}

nanoparticles efficiently redirected Bcl-x pre-mRNA splicing and significantly reduced the tumour burden in mice with rapidly growing and highly tumorigenic lung metastases [73]. Soon after, Bauman et al. [74] presented the first demonstration of Bcl-x SSO efficacy in tumours in vivo. Recently, a Bcl-x SSO, modified using 2'-O-methoxyethylphosphorothioate and delivered with a cationic lipid into glioma and astrocyte cell lines, modulated the RNA splicing of Bcl-x pre-mRNA in glioma cell lines [75]. Table 2 provides examples of SSOs shown to be effective in the correction of cancer-related splicing isoform expression. This may represent a potential strategy for treating cancer. The potential of therapeutic SSOs is rather promising, with numerous clinical trials currently ongoing.

\section{Small molecules as drugs for regulating RNA splicing in cancer}

Additionally, small molecules as drugs have been developed that target RNA splicing in an effort to block the abnormal recruitment of splicing factors to mutant sequences [76]. Several natural compounds and synthetic derivatives as inhibitors have been reported to inhibit RNA splicing (Table 3). These inhibitors are cytotoxic at higher concentrations, although at lower concentrations these inhibitors were used as drugs for modulating RNA splicing in cancer. The earliest splicing modulators were FR901464 and its acetylated derivate spliceostatin A. In solid tumours, treatment with FR901464 reduced tumour size by $80 \%$ [29]. GEX1A and sudemycin D6 achieved a reduction of tumour size by 80 and $50 \%$, respectively [77]. Similarly, pladienolide $\mathrm{B}$ was effective in reducing xenograft tumours by $60 \%$ [78]. The pladienolide B synthetic E7107 was tested in a phase 1 clinical trial with patients presenting different types of solid tumours [29]. However, due to the structural complexity of these molecules, their research and development has been significantly constrained. Recently, additional small molecule splicing inhibitors were identified, such as caffeine, digoxin, amiloride, sudemycins et al. In cervical cancer cells, caffeine and digoxin could reduce expression of the serine/arginine-rich splicing factor 3 (SRSF3) and increase expression of a p53b isoform. This change was accompanied by increased DNA damage and apoptosis [79]. Actually, caffeine and digoxin have been used in clinical application. Tang et al. suggested that 0.2 $\mathrm{mM}$ amiloride modulated cell radiosensitivity and RNA splicing of the apoptotic peptidase activating factor 1

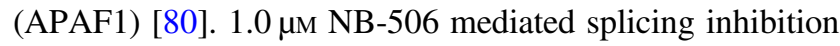
by preventing complete phosphorylation of the SF2/ASF SR protein, affected apoptosis and tumour progression [81]. Madrasin at lower concentrations induced cell cycle arrest and apoptosis, and modulates splicing of multiple premRNAs in cancer cells [82]. Sudemycins can regulate the production of alternatively spliced RNA transcripts and these alterations are more prevalent in tumour, as compared to normal cells, following drug exposure [83]. RNAbinding protein 39 (RBM39) is associated with pre-mRNA splicing factors; its inactivation by indisulam caused aberrant pre-mRNA splicing in many cancer cell lines [84]. Ibrutinib's role in therapy was further expanded recently when the US Food and Drug Administration approved its use in both frontline and salvage treatment of patients with chronic lymphocytic leukaemia [85]. Recent clinical trials using selective pharmacologic targeting of CLDN18.2 and PI3K $\gamma$ have demonstrated their potential to control cancer [86]. These findings suggested that small molecules that act as a general inhibitor of splicing may represent a novel avenue for development of new anti-cancer agents.

\section{Methodologies for detecting aberrant splicing isoform in cancer}

The investigation of splicing changes in cancer has been shaped by the development of techniques (Table 4). For the relative quantification of isoform expression, real-time qPCR has been the gold standard for over a decade. More recently, droplet digital PCR is becoming widely implemented [87]. Nevertheless, identification of informative 
Table 3 Small molecules as drugs for inhibiting RNA splicing in cancer
Table 4 Overview of diagnostic methodologies of aberrant splicing isoforms in cancer

\begin{tabular}{|c|c|c|c|c|c|c|}
\hline Target & \multicolumn{2}{|c|}{ Drugs } & \multicolumn{3}{|c|}{ Short description } & Refs \\
\hline APAF1 & \multicolumn{2}{|c|}{ Amioride } & \multicolumn{3}{|c|}{ Radiosensitivity in glioblastoma multiforme cells } & {$[80]$} \\
\hline AR & \multicolumn{2}{|c|}{$6 \mathrm{BIO}$} & \multicolumn{3}{|c|}{ Drug sensitivity in prostate cancer cells } & [111] \\
\hline BTK & \multicolumn{2}{|c|}{ Ibrutinib } & \multicolumn{3}{|c|}{ Target kinases in chronic lymphocytic leukaemia } & {$[85]$} \\
\hline RBM39 & \multicolumn{2}{|c|}{ Indisulam } & \multicolumn{3}{|c|}{ RBM39 degradation in the hematopoietic and lymphoid tissues } & {$[84]$} \\
\hline $\mathrm{SF} 3 \mathrm{~b}$ & \multicolumn{2}{|c|}{ Spliceostatin A } & \multicolumn{3}{|c|}{ Display anti-proliferative effects in HeLa cells } & [112] \\
\hline $\mathrm{SF} 3 \mathrm{~b}$ & \multicolumn{2}{|c|}{ FR901464 } & \multicolumn{3}{|c|}{ Anti-tumour activity in lung cancer, breast cancer and et al } & \\
\hline SF3b & \multicolumn{2}{|c|}{ E7107 } & \multicolumn{3}{|c|}{ Block spliceosome assembly in patients with solid tumours } & [113] \\
\hline SF3b & \multicolumn{2}{|c|}{ Meayamycin B } & \multicolumn{3}{|c|}{ Induction of apoptosis in head and neck cancer cells } & [114] \\
\hline SF3b & \multicolumn{2}{|c|}{ Jerantinine A } & \multicolumn{3}{|c|}{ Anti-tumour activity by targeting splicing factor in breast cancer } & [115] \\
\hline $\mathrm{SF} 3 \mathrm{~b}$ & \multicolumn{2}{|c|}{ Sudemycin } & \multicolumn{3}{|c|}{ Induce antitumour response in chronic lymphocytic leukaemia } & [116] \\
\hline $\mathrm{SF} 3 \mathrm{~b}$ & \multicolumn{2}{|c|}{ Pladienolides } & \multicolumn{3}{|c|}{ Display anti-proliferative effects in HeLa cells } & [117] \\
\hline $\mathrm{SF} 3 \mathrm{~b}$ & \multicolumn{2}{|c|}{ GEX1A } & \multicolumn{3}{|c|}{ Anti-tumour activity by targeting SAP155 protein in HeLa cells } & [118] \\
\hline Step 1 & \multicolumn{2}{|c|}{ Isoginkgetin } & \multicolumn{3}{|c|}{ Anti-tumour effect by splicing inhibition in HEK293 cell lines } & [119] \\
\hline Step 1 & \multicolumn{2}{|c|}{ Madrasin } & \multicolumn{3}{|c|}{ Modulate pre-mRNAs splicing in both HeLa and HEK293 cells } & {$[82]$} \\
\hline Step 1 & Caffe & & Inhibit $\mathrm{t}$ & e survival of different $t$ & ypes of tumour cells & [79] \\
\hline SRSF3 & Digor & & Inductio & of apoptosis in HeLa & cells & [120] \\
\hline SR & NB-5 & & Phospho & ylate SF2/ASF, affect a & poptosis in leukaemia cell line & {$[81]$} \\
\hline Level & & Method & & Material & Property & Refs \\
\hline Transcript lev & evel & RT-PCR & & Cell lines \& tissues & Gold-standard for known gene & {$[61]$} \\
\hline & & Real time $\mathrm{F}$ & & & & \\
\hline & & Digital dro & et PCR & & Single-cell capacity & [87] \\
\hline & & Exon junct & $n$ array & Cancer cell lines & Genome-wide survey of splicing & {$[88]$} \\
\hline & & Exon array & & $\begin{array}{l}\text { Colon cancer; } \\
\text { HNSCC }\end{array}$ & $\begin{array}{l}\text { The GeneChip Human Exon } \\
\text { array }\end{array}$ & [121] \\
\hline & & Tiling array & & Breast cancer & Detection of intron retention & [91] \\
\hline & & RNA-seq & & $\begin{array}{l}\text { Different cancer } \\
\text { types }\end{array}$ & $\begin{array}{l}\text { Novel transcripts and gene } \\
\text { fusions }\end{array}$ & [122] \\
\hline & & Primer Seq & encing & Human heart \& testes & Software of RT-PCR primers & [123] \\
\hline Protein level & & Quantitativ & imaging & Breast cancer & $\begin{array}{l}\text { Combination of probes and } \\
\text { imaging }\end{array}$ & [124] \\
\hline & & Peptidomic & approach & & Based on the PEPPI & [96] \\
\hline & & Western bl & & $\begin{array}{l}\text { Different cancer } \\
\text { types }\end{array}$ & Isoform-specific antibodies & [99] \\
\hline & & Immunoh & emistry & & & \\
\hline & & Immunoflu & scence & & & \\
\hline
\end{tabular}

splice isoforms by this process is still laborious and the multiplexing capacity is limited. DNA-microarrays have provided a more high-throughput approach for studying transcriptomes. Zhang et al. [88] developed an assay based on junction microarrays and profiled alternatively spliced mRNA isoforms for prostate cancer classification. Another similar study on breast cancer by Lapuk et al. reported 181 candidate RNA splicing events in 156 genes [89]. Whole-genome exon arrays were used to study genome-wide RNA splicing events in colon, urinary bladder, prostate, breast and non-small cell lung cancer [90]. Furthermore, genomic tiling arrays provided an opportunity to systematically assess intron retention events arising from RNA splicing, which might be important for cancer [91]. A limitation of DNA microarrays is the fact that unknown transcripts or abnormal splicing isoforms cannot be detected. Recently, RNAsequencing has become the state-of-the-art technology to determine splicing changes [92]. This is expensive but can be highly sensitive. Importantly, it can discover new isoforms without prior knowledge of the exact sequence. Nellore et al. produced the most comprehensive view of human transcriptome splicing to date [93]. For particular diseases, survey studies were performed, such as an 
analysis of pancreatic ductal adenocarcinoma, identifying 1354 genes that were expressed in RNA splicing isoforms [94]. Extensive studies have emerged on using RNA-Seq to study AS in cancer, and some studies are shown in Table 4. However, how to handle the massive data generated from RNA-Seq is still a major challenge to its applications.

Comprehensive studies have also been performed at the protein level. For mass spectrometry, databases exist, in which the proteome-wide peptide content of isoform proteins is accessible that was computationally produced from sequence information so as to allow the detection of RNA splicing events at the proteome level [95]. PEPtidomics Protein Isoform Database, a comprehensive database of computationally synthesised human peptides was developed to study genetic variations and AS events at the proteome level. Zhang et al. [96] performed MS with PEPPI to analyse, identify and characterise novel AS isoform biomarkers from breast cancer. Another process for screening protein isoforms would be microarrays consisting of isoform-specific antibodies or other binder formats [97]. A limitation for this but also other analysis procedures is still the access to a set of binders that are sufficiently specific for the various protein isoforms. Nanobodies or entirely artificial structures such as DARPins [98] may be better suited to bind three-dimensional epitopes with high accuracy and thus discriminate better between protein isoforms. In another microarray-based approach, a process was developed by which the spliceisoform proteins are made accessible that are present in samples of individual patients without needing any prior knowledge [99]. This could represent a route to personal diagnosis, which eventually would translate to other platforms, however, which are better suited for routine use than protein arrays. Up to now, we still cannot do further research of some aberrant splicing isoforms. Firstly, we cannot find the commercial antibody. One reason is that the sequence similarity of isoforms is quite high. The other reason is that the different sequence between different isoforms is not fit to be antigen to make antibody. If we do not have the antibody, it is difficult to study the biological function in the protein level in the cancer cell. Although there is still a bottleneck in the research of alternative splicing in cancer, a more global picture of the role of alternative RNA splicing in human cancer is beginning to emerge.

\section{Concluding remarks}

From a large body of experimental data, it has become increasingly clear that aberrant splicing isoforms play a critical role in cancer. While clinical trials utilising aberrant splicing isoforms profiling for patients prognosis and clinical response are now underway. Now we are at a point, at which a more comprehensive picture of the number and effects of alternative splicing as well as their part in the overall regulatory network begins to emerge, much work still needs to be done to provide sufficient information for translating this knowledge into clinical application. There are still many outstanding questions. Firstly, how specific are particular aberrant splicing isoforms and the resulting protein isoforms for cancer tissues? Secondly, what are the mechanisms by which small molecules modulate target gene splicing and thus inhibit tumour growth of human cancer? Thirdly, can protein isoforms that results from alternative RNA splicing in individual patients with cancer provide treatment options as part of a precision medicine approach? Last but not least, could splice variations be better reversed by applying new genome editing processes, such as CRISPR-Cas, or would proteomic procedures, such as provision of specific antibodies against the tumour-specific protein isoform do a better and/or technically superior job in clinical application? Overall, it becomes increasingly clear, that aberrant splicing isoforms plays a crucial role in cancer therapy. Although this would only be a beginning, it would represent a start into a new area of cancer therapy.

Acknowledgements This work was supported by grants of the national Key R\&D project of the Chinese Ministry of Science and Technology (2016YFC0904600), the Key Program of the National Natural Science Foundation of China (U1432248, U1632270), the National Natural Science Foundation of China (11675234, 11575262), the Affinomics consortium funded by the European Union (Health-F42010-241481), and the Natural Science Foundation of Gansu (17JR5RA310).

\section{Compliance with ethical standards}

Conflict of interest The authors declare that they have no conflict of interest.

Open Access This article is licensed under a Creative Commons Attribution 4.0 International License, which permits use, sharing, adaptation, distribution and reproduction in any medium or format, as long as you give appropriate credit to the original author(s) and the source, provide a link to the Creative Commons license, and indicate if changes were made. The images or other third party material in this article are included in the article's Creative Commons license, unless indicated otherwise in a credit line to the material. If material is not included in the article's Creative Commons license and your intended use is not permitted by statutory regulation or exceeds the permitted use, you will need to obtain permission directly from the copyright holder. To view a copy of this license, visit http://creativecommons. org/licenses/by/4.0/.

\section{References}

1. Venter JC, Adams MD, Myers EW, Li PW, Mural RJ, Sutton $\mathrm{GG}$, et al. The sequence of the human genome. Science. 2001;291:1304-51. 
2. Pan Q, Shai O, Lee LJ, Frey BJ, Blencowe BJ. Deep surveying of alternative splicing complexity in the human transcriptome by high-throughput sequencing. Nat Genet. 2008;40:1413-5.

3. Blencowe BJ. The relationship between alternative splicing and proteomic complexity. Trends Biochem Sci. 2017;42:407-8.

4. Zhang X, Chen MH, Wu X, Kodani A, Fan J, Doan R, et al. Cell-type-specific alternative splicing governs cell fate in the developing cerebral cortex. Cell. 2016;166:1147-62 e1115.

5. Dvinge H, Kim E, Abdel-Wahab O, Bradley RK. RNA splicing factors as oncoproteins and tumour suppressors. Nat Rev Cancer. 2016;16:413-30.

6. Paronetto MP, Passacantilli I, Sette C. Alternative splicing and cell survival: from tissue homeostasis to disease. Cell Death Differ. 2016;23:1919-29.

7. Wahl MC, Will CL, Luhrmann R. The spliceosome: design principles of a dynamic RNP machine. Cell. 2009;136:701-18.

8. Ge Y, Porse BT. The functional consequences of intron retention: alternative splicing coupled to NMD as a regulator of gene expression. Bioessays. 2014;36:236-43.

9. Grellscheid S, Dalgliesh C, Storbeck M, Best A, Liu Y, Jakubik $\mathrm{M}$, et al. Identification of evolutionarily conserved exons as regulated targets for the splicing activator tra2beta in development. PLoS Genet. 2011;7:e1002390.

10. Keren H, Lev-Maor G, Ast G. Alternative splicing and evolution: diversification, exon definition and function. Nat Rev Genet. 2010;11:345-55.

11. Jin Y, Dong H, Shi Y, Bian L. Mutually exclusive alternative splicing of pre-mRNAs. Wiley Interdiscip Rev RNA. 2018;9: e1468.

12. Brady LK, Wang H, Radens CM, Bi Y, Radovich M, Maity A, et al. Transcriptome analysis of hypoxic cancer cells uncovers intron retention in EIF2B5 as a mechanism to inhibit translation. PLoS Biol. 2017;15:e2002623.

13. Yang Z, Xie L, Han L, Qu X, Yang Y, Zhang Y, et al. Circular RNAs: regulators of cancer-related signaling pathways and potential diagnostic biomarkers for human cancers. Theranostics. 2017;7:3106-17.

14. Black DL. Mechanisms of alternative pre-messenger RNA splicing. Annu Rev Biochem. 2003;72:291-336.

15. Yang Y, Walsh CE. Spliceosome-mediated RNA trans-splicing. Mol Ther. 2005;12:1006-12.

16. Wang Z, Burge CB. Splicing regulation: from a parts list of regulatory elements to an integrated splicing code. RNA. 2008;14:802-13.

17. Kedzierska H, Piekielko-Witkowska A. Splicing factors of SR and hnRNP families as regulators of apoptosis in cancer. Cancer Lett. 2017;396:53-65.

18. Kwabi-Addo B, Ren C, Ittmann M. DNA methylation and aberrant expression of Sprouty1 in human prostate cancer. Epigenetics. 2009;4:54-61.

19. Patounas O, Papacharalampous I, Eckerich C, Markopoulos GS, Kolettas E, Fackelmayer FO. A novel splicing isoform of protein arginine methyltransferase 1 (PRMT1) that lacks the dimerization arm and correlates with cellular malignancy. J Cell Biochem. 2018;119:2110-23.

20. Canavese M, Ngo DT, Maddern GJ, Hardingham JE, Price TJ, Hauben E. Biology and therapeutic implications of VEGF-A splice isoforms and single-nucleotide polymorphisms in colorectal cancer. Int J Cancer. 2017;140:2183-91.

21. Augello MA, Berman-Booty LD, Carr R 3rd, Yoshida A, Dean $\mathrm{JL}$, et al. Consequence of the tumor-associated conversion to cyclin D1b. EMBO Mol Med. 2015;7:628-47.

22. Wang Y, Dean JL, Millar EK, Tran TH, McNeil CM, Burd CJ, et al. Cyclin D1b is aberrantly regulated in response to therapeutic challenge and promotes resistance to estrogen antagonists. Cancer Res. 2008;68:5628-38.
23. Augello MA, Burd CJ, Birbe R, McNair C, Ertel A, Magee MS, et al. Convergence of oncogenic and hormone receptor pathways promotes metastatic phenotypes. J Clin Invest. 2013;123:493508.

24. Li R, An SJ, Chen ZH, Zhang GC, Zhu JQ, Nie Q, et al. Expression of cyclin D1 splice variants is differentially associated with outcome in non-small cell lung cancer patients. Hum Pathol. 2008;39:1792-801.

25. Guo W, Wang C, Guo Y, Shen S, Guo X, Kuang G, et al. RASSF5A, a candidate tumor suppressor, is epigenetically inactivated in esophageal squamous cell carcinoma. Clin Exp Metastasis. 2015;32:83-98.

26. Wang L, Duke L, Zhang PS, Arlinghaus RB, Symmans WF, Sahin A, et al. Alternative splicing disrupts a nuclear localization signal in spleen tyrosine kinase that is required for invasion suppression in breast cancer. Cancer Res. 2003;63:4724-30.

27. Nasomyon T, Samphao S, Sangkhathat S, Mahattanobon S, Graidist P. Correlation of Wilms' tumor 1 isoforms with HER2 and ER-alpha and its oncogenic role in breast cancer. Anticancer Res. 2014;34:1333-42.

28. Yae T, Tsuchihashi K, Ishimoto T, Motohara T, Yoshikawa M, Yoshida GJ, et al. Alternative splicing of CD44 mRNA by ESRP1 enhances lung colonization of metastatic cancer cell. Nat Commun. 2012;3:883.

29. Salton M, Misteli T. Small molecule modulators of pre-mRNA splicing in cancer therapy. Trends Mol Med. 2016;22: 28-37.

30. Heider KH, Kuthan H, Stehle G, Munzert G. CD44v6: a target for antibody-based cancer therapy. Cancer Immunol Immunother. 2004;53:567-79.

31. Todaro M, Gaggianesi M, Catalano V, Benfante A, Iovino F, Biffoni M, et al. CD44v6 is a marker of constitutive and reprogrammed cancer stem cells driving colon cancer metastasis. Cell Stem Cell. 2014;14:342-56.

32. Spiegelberg D, Nilvebrant J. CD44v6-targeted imaging of head and neck squamous cell carcinoma: antibody-based approaches. Contrast Media Mol Imaging. 2017;2017:2709547.

33. Takino T, Nakada M, Miyamori H, Yamashita J, Yamada KM, Sato H. CrkI adapter protein modulates cell migration and invasion in glioblastoma. Cancer Res. 2003;63:2335-7.

34. Hatami R, Sieuwerts AM, Izadmehr S, Yao Z, Qiao RF, Papa L, et al. KLF6-SV1 drives breast cancer metastasis and is associated with poor survival. Sci Transl Med. 2013;5:169ra112.

35. English WR, Lunt SJ, Fisher M, Lefley DV, Dhingra M, Lee YC, et al. Differential expression of VEGFA isoforms regulates metastasis and response to anti-VEGFA therapy in sarcoma. Cancer Res. 2017;77:2633-46.

36. Goel HL, Gritsko T, Pursell B, Chang C, Shultz LD, Greiner DL, et al. Regulated splicing of the alpha6 integrin cytoplasmic domain determines the fate of breast cancer stem cells. Cell Rep. 2014;7:747-61.

37. Chang C, Goel HL, Gao H, Pursell B, Shultz LD, Greiner DL, et al. A laminin 511 matrix is regulated by TAZ and functions as the ligand for the alpha6Bbetal integrin to sustain breast cancer stem cells. Genes Dev. 2015;29:1-6.

38. Pflaum J, Schlosser S, Muller M. p53 family and cellular stress responses in cancer. Front Oncol. 2014;4:285.

39. Boise LH, Gonzalez-Garcia M, Postema CE, Ding L, Lindsten T, Turka LA, et al. bcl-x, a bcl-2-related gene that functions as a dominant regulator of apoptotic cell death. Cell. 1993;74:597608.

40. Kopechek JA, Carson AR, McTiernan CF, Chen X, Hasjim B, Lavery L, et al. Ultrasound targeted microbubble destructionmediated delivery of a transcription factor decoy inhibits STAT3 signaling and tumor growth. Theranostics. 2015;5:137887. 
41. Fuzio P, Napoli A, Ciampolillo A, Lattarulo S, Pezzolla A, Nuzziello $\mathrm{N}$, et al. Clusterin transcript variants expression in thyroid tumor: a potential marker of malignancy? BMC Cancer. 2015;15:349.

42. Guan FH, Bailey CG, Metierre C, O'Young P, Gao D, Khoo TL, et al. The antiproliferative ELF2 isoform, ELF2B, induces apoptosis in vitro and perturbs early lymphocytic development in vivo. J Hematol Oncol. 2017;10:75.

43. Yang Y, Hu W, Feng S, Ma J, Wu M. RIP3 beta and RIP3 gamma, two novel splice variants of receptor-interacting protein 3 (RIP3), downregulate RIP3-induced apoptosis. Biochem Biophys Res Commun. 2005;332:181-7.

44. Han Y, Huang W, Liu J, Liu D, Cui Y, Huang R, et al. Triptolide inhibits the AR signaling pathway to suppress the proliferation of enzalutamide resistant prostate cancer cells. Theranostics. 2017;7:1914-27.

45. Antonarakis ES, Lu C, Luber B, Wang H, Chen Y, Zhu Y, et al. Clinical significance of androgen receptor splice variant-7 mRNA detection in circulating tumor cells of men with metastatic castration-resistant prostate cancer treated with first- and second-line abiraterone and enzalutamide. J Clin Oncol. 2017;35:2149-56.

46. Seitz AK, Thoene S, Bietenbeck A, Nawroth R, Tauber R, Thalgott M, et al. AR-V7 in peripheral whole blood of patients with castration-resistant prostate cancer: association with treatment-specific outcome under abiraterone and enzalutamide. Eur Urol. 2017;72:828-34.

47. Van Etten JL, Nyquist M, Li Y, Yang R, Ho Y, Johnson R, et al. Targeting a single alternative polyadenylation site coordinately blocks expression of androgen receptor mRNA splice variants in prostate cancer. Cancer Res. 2017;77:5228-35.

48. Vegran F, Mary R, Gibeaud A, Mirjolet C, Collin B, Oudot A, et al. Survivin-3B potentiates immune escape in cancer but also inhibits the toxicity of cancer chemotherapy. Cancer Res. 2013;73:5391-401.

49. Wang Y, Bernhardy AJ, Cruz C, Krais JJ, Nacson J, Nicolas E, et al. The BRCA1-delta11q alternative splice isoform bypasses germline mutations and promotes therapeutic resistance to PARP inhibition and cisplatin. Cancer Res. 2016;76:2778-90.

50. Haag C, Stadel D, Zhou S, Bachem MG, Moller P, Debatin KM, et al. Identification of c-FLIP(L) and c-FLIP(S) as critical regulators of death receptor-induced apoptosis in pancreatic cancer cells. Gut. 2011;60:225-37.

51. Hughes MA, Powley IR, Jukes-Jones R, Horn S, Feoktistova M, Fairall L, et al. Co-operative and hierarchical binding of c-FLIP and caspase-8: a unified model defines how c-FLIP isoforms differentially control cell fate. Mol Cell. 2016;61:834-49.

52. Xiong W, Gao D, Li Y, Liu X, Dai P, Qin J, et al. Genome-wide profiling of chemoradiationinduced changes in alternative splicing in colon cancer cells. Oncol Rep. 2016;36:2142-50.

53. Leskov KS, Araki S, Lavik JP, Gomez JA, Gama V, Gonos ES, et al. CRM1 protein-mediated regulation of nuclear clusterin (nCLU), an ionizing radiation-stimulated, Bax-dependent prodeath factor. J Biol Chem. 2011;286:40083-90.

54. Palve VC, Teni TR. Association of anti-apoptotic Mcl-1L isoform expression with radioresistance of oral squamous carcinoma cells. Radiat Oncol. 2012;7:135.

55. Dalenc F, Drouet J, Ader I, Delmas C, Rochaix P, Favre G, et al. Increased expression of a $\mathrm{COOH}$-truncated nucleophosmin resulting from alternative splicing is associated with cellular resistance to ionizing radiation in HeLa cells. Int $\mathrm{J}$ Cancer. 2002;100:662-8.

56. Muller M, Schleithoff ES, Stremmel W, Melino G, Krammer PH, Schilling T. One, two, three-p53, p63, p73 and chemosensitivity. Drug Resist Updat. 2006;9:288-306.
57. Liu SS, Chan KY, Leung RC, Law HK, Leung TW, Ngan HY. Enhancement of the radiosensitivity of cervical cancer cells by overexpressing p73alpha. Mol Cancer Ther. 2006;5:1209-15.

58. Di CX, Yang LN, Zhang H, An LZ, Zhang X, Ma XF, et al. Effects of carbon-ion beam or X-ray irradiation on anti-apoptosis DeltaNp73 expression in HeLa cells. Gene. 2013;515:208-13.

59. Pfeifer D, Wallin A, Holmlund B, Sun XF. Protein expression following gamma-irradiation relevant to growth arrest and apoptosis in colon cancer cells. J Cancer Res Clin Oncol. 2009;135:1583-92.

60. Di C, Sun C, Li H, Si J, Zhang H, Han L, et al. Diallyl disulfide enhances carbon ion beams-induced apoptotic cell death in cervical cancer cells through regulating Tap73/DeltaNp73. Cell Cycle. 2015;14:3725-33.

61. Di CX, Han L, Zhang H, Xu S, Mao AH, Sun C, et al. Diallyl disulfide attenuated carbon ion irradiation-induced apoptosis in mouse testis through changing the ratio of Tap73/DeltaNp73 via mitochondrial pathway. Sci Rep. 2015;5:16020.

62. Woll S, Schlitter AM, Dhaene K, Roller M, Esposito I, Sahin U, et al. Claudin 18.2 is a target for IMAB362 antibody in pancreatic neoplasms. Int J Cancer. 2014;134:731-9.

63. Kaneda MM, Messer KS, Ralainirina N, Li H, Leem CJ, Gorjestani S, et al. PI3Kgamma is a molecular switch that controls immune suppression. Nature. 2016;539:437-42.

64. De Henau O, Rausch M, Winkler D, Campesato LF, Liu C, Cymerman DH, et al. Overcoming resistance to checkpoint blockade therapy by targeting PI3Kgamma in myeloid cells. Nature. 2016;539:443-7.

65. Gotwals P, Cameron S, Cipolletta D, Cremasco V, Crystal A, Hewes B, et al. Prospects for combining targeted and conventional cancer therapy with immunotherapy. Nat Rev Cancer. 2017; 17:286-301.

66. Havens MA, Hastings ML. Splice-switching antisense oligonucleotides as therapeutic drugs. Nucleic Acids Res. 2016;44:6549-63.

67. Summerton J. Morpholino antisense oligomers: the case for an RNase H-independent structural type. Biochim Biophys Acta. 1999;1489:141-58.

68. Rigo F, Seth PP, Bennett CF. Antisense oligonucleotide-based therapies for diseases caused by pre-mRNA processing defects. Adv Exp Med Biol. 2014;825:303-52.

69. Palhais B, Praestegaard VS, Sabaratnam R, Doktor TK, Lutz S, Burda P, et al. Splice-shifting oligonucleotide (SSO) mediated blocking of an exonic splicing enhancer (ESE) created by the prevalent c. $903+469$ T $>$ C MTRR mutation corrects splicing and restores enzyme activity in patient cells. Nucleic Acids Res. 2015;43:4627-39.

70. Gupta K, Elkon J, El-Bahesh E, Aragon-Ching JB. The utility of chemotherapy in the treatment of metastatic prostate cancer. Anticancer Agents Med Chem. 2016;16:1166-71.

71. Stein CA, Castanotto D. FDA-approved oligonucleotide therapies in 2017. Mol Ther. 2017;25:1069-75.

72. Mercatante DR, Mohler JL, Kole R. Cellular response to an antisense-mediated shift of Bcl-x pre-mRNA splicing and antineoplastic agents. J Biol Chem. 2002;277:49374-82.

73. Bauman JA, Li SD, Yang A, Huang L, Kole R. Anti-tumor activity of splice-switching oligonucleotides. Nucleic Acids Res. 2010;38:8348-56.

74. Bauman JA, Kole R. Modulation of RNA splicing as a potential treatment for cancer. Bioeng Bugs. 2011;2:125-8.

75. Li Z, Li Q, Han L, Tian N, Liang Q, Li Y, et al. Pro-apoptotic effects of splice-switching oligonucleotides targeting Bcl-x premRNA in human glioma cell lines. Oncol Rep. 2016;35:1013-9.

76. Scotti MM, Swanson MS. RNA mis-splicing in disease. Nat Rev Genet. 2016;17:19-32. 
77. Sakai Y, Tsujita T, Akiyama T, Yoshida T, Mizukami T, Akinaga $\mathrm{S}$, et al. GEX1 compounds, novel antitumor antibiotics related to herboxidiene, produced by Streptomyces sp. II. The effects on cell cycle progression and gene expression. J Antibiot (Tokyo). 2002;55:863-72.

78. Mizui Y, Sakai T, Iwata M, Uenaka T, Okamoto K, Shimizu H, et al. Pladienolides, new substances from culture of Streptomyces platensis Mer-11107. III. In vitro and in vivo antitumor activities. J Antibiot (Tokyo). 2004;57:188-96.

79. Lu GY, Huang SM, Liu ST, Liu PY, Chou WY, Lin WS. Caffeine induces tumor cytotoxicity via the regulation of alternative splicing in subsets of cancer-associated genes. Int $\mathbf{J}$ Biochem Cell Biol. 2014;47:83-92.

80. Tang JY, Chang HW, Chang JG. Modulating roles of amiloride in irradiation-induced antiproliferative effects in glioblastoma multiforme cells involving Akt phosphorylation and the alternative splicing of apoptotic genes. DNA Cell Biol. 2013;32:50410.

81. Pilch B, Allemand E, Facompre M, Bailly C, Riou JF, Soret J, et al. Specific inhibition of serine- and arginine-rich splicing factors phosphorylation, spliceosome assembly, and splicing by the antitumor drug NB-506. Cancer Res. 2001;61:6876-84.

82. Pawellek A, McElroy S, Samatov T, Mitchell L, Woodland A, Ryder $\mathrm{U}$, et al. Identification of small molecule inhibitors of premRNA splicing. J Biol Chem. 2014;289:34683-98.

83. Fan L, Lagisetti C, Edwards CC, Webb TR, Potter PM. Sudemycins, novel small molecule analogues of FR901464, induce alternative gene splicing. ACS Chem Biol. 2011;6:582-9.

84. Han T, Goralski M, Gaskill N, Capota E, Kim J, Ting TC. et al. Anticancer sulfonamides target splicing by inducing RBM39 degradation via recruitment to DCAF15. Science. 2017;356: eaal3755

85. Khan M, Gibbons JL, Ferrajoli A. Spotlight on ibrutinib and its potential in frontline treatment of chronic lymphocytic leukemia. Onco Targets Ther. 2017;10:1909-14.

86. Micke P, Mattsson JS, Edlund K, Lohr M, Jirstrom K, Berglund A, et al. Aberrantly activated claudin 6 and 18.2 as potential therapy targets in non-small-cell lung cancer. Int $\mathrm{J}$ Cancer. 2014;135:2206-14.

87. Van Heetvelde M, Van Loocke W, Trypsteen W, Baert A, Vanderheyden K, Crombez B, et al. Evaluation of relative quantification of alternatively spliced transcripts using droplet digital PCR. Biomol Detect Quantif. 2017;13:40-48.

88. Zhang C, Li HR, Fan JB, Wang-Rodriguez J, Downs T, Fu XD, et al. Profiling alternatively spliced mRNA isoforms for prostate cancer classification. BMC Bioinform. 2006;7:202.

89. Lapuk A, Marr H, Jakkula L, Pedro H, Bhattacharya S, Purdom E, et al. Exon-level microarray analyses identify alternative splicing programs in breast cancer. Mol Cancer Res. 2010;8:961-74.

90. Van Moerbeke M, Kasim A, Talloen W, Reumers J, Gohlmann HWH, Shkedy Z. A random effects model for the identification of differential splicing (REIDS) using exon and HTA arrays. BMC Bioinform. 2017;18:273.

91. Jonsson G, Staaf J, Olsson E, Heidenblad M, VallonChristersson J, Osoegawa K, et al. High-resolution genomic profiles of breast cancer cell lines assessed by tiling BAC array comparative genomic hybridization. Genes Chromosomes Cancer. 2007;46:543-58.

92. Anczukow O, Akerman M, Clery A, Wu J, Shen C, Shirole NH, et al. SRSF1-regulated alternative splicing in breast cancer. Mol Cell. 2015;60:105-17.

93. Nellore A, Collado-Torres L, Jaffe AE, Alquicira-Hernandez J, Wilks C, Pritt J, et al. Rail-RNA: scalable analysis of RNA-seq splicing and coverage. Bioinformatics. 2017;33:4033-40.
94. Wang J, Dumartin L, Mafficini A, Ulug P, Sangaralingam A, Alamiry NA, et al. Splice variants as novel targets in pancreatic ductal adenocarcinoma. Sci Rep. 2017;7:2980.

95. Zhou A, Zhang F, Chen JY. PEPPI: a peptidomic database of human protein isoforms for proteomics experiments. BMC Bioinform. 2010;11:S7. Suppl 6

96. Zhang F, Wang M, Michael T, Drabier R. Novel alternative splicing isoform biomarkers identification from high-throughput plasma proteomics profiling of breast cancer. BMC Syst Biol. 2013;7:S8. Suppl 5

97. Hoheisel JD, Alhamdani MS, Schroder C. Affinity-based microarrays for proteomic analysis of cancer tissues. Proteom Clin Appl. 2013;7:8-15.

98. Pluckthun A. Designed ankyrin repeat proteins (DARPins): binding proteins for research, diagnostics, and therapy. Annu Rev Pharmacol Toxicol. 2015;55:489-511.

99. Syafrizayanti, Lueong SS, Di C, Schaefer JV, Pluckthun A, Hoheisel JD. Personalised proteome analysis by means of protein microarrays made from individual patient samples. Sci Rep. 2017;7:39756.

100. Bissanum R, Lirdprapamongkol K, Svasti J, Navakanitworakul $\mathrm{R}$, Kanokwiroon K. The role of WT1 isoforms in vasculogenic mimicry and metastatic potential of human triple negative breast cancer cells. Biochem Biophys Res Commun. 2017;494:256262.

101. Liu R, Wang Q, Xu G, Li K, Zhou L, Xu B. The adaptor protein CrkII regulates IGF-1-induced biological behaviors of pancreatic ductal adenocarcinoma. Tumour Biol. 2016;37:817-22.

102. Kralovicova J, Moreno PM, Cross NC, Pego AP, Vorechovsky I. Antisense oligonucleotides modulating activation of a nonsensemediated RNA decay switch exon in the ATM gene. Nucleic Acid Ther. 2016;26:392-400.

103. Smith LD, Leme de Calais F, Raponi M, Mellone M, Buratti E, Blaydes JP, et al. Novel splice-switching oligonucleotide promotes BRCA1 aberrant splicing and susceptibility to PARP inhibitor action. Int J Cancer. 2017;140:1564-70.

104. Wan J, Sazani P, Kole R. Modification of HER2 pre-mRNA alternative splicing and its effects on breast cancer cells. Int $\mathrm{J}$ Cancer. 2009;124:772-7.

105. Nielsen TO, Sorensen S, Dagnaes-Hansen F, Kjems J, Sorensen BS. Directing HER4 mRNA expression towards the CYT2 isoform by antisense oligonucleotide decreases growth of breast cancer cells in vitro and in vivo. Br J Cancer. 2013;108:2291-8.

106. Comiskey DF Jr., Jacob AG, Singh RK, Tapia-Santos AS, Chandler DS. Splicing factor SRSF1 negatively regulates alternative splicing of MDM2 under damage. Nucleic Acids Res. 2015;43:4202-18.

107. Dewaele M, Tabaglio T, Willekens K, Bezzi M, Teo SX, Low $\mathrm{DH}$, et al. Antisense oligonucleotide-mediated MDM4 exon 6 skipping impairs tumor growth. J Clin Invest. 2016;126:68-84.

108. Calabretta S, Bielli P, Passacantilli I, Pilozzi E, Fendrich V, Capurso G, et al. Modulation of PKM alternative splicing by PTBP1 promotes gemcitabine resistance in pancreatic cancer cells. Oncogene. 2016;35:2031-9.

109. Zammarchi F, de Stanchina E, Bournazou E, Supakorndej T, Martires K, Riedel E, et al. Antitumorigenic potential of STAT3 alternative splicing modulation. Proc Natl Acad Sci USA. 2011;108:17779-84.

110. Renshaw J, Orr RM, Walton MI, Te Poele R, Williams RD, Wancewicz EV, et al. Disruption of WT1 gene expression and exon 5 splicing following cytotoxic drug treatment: antisense down-regulation of exon 5 alters target gene expression and inhibits cell survival. Mol Cancer Ther. 2004;3:1467-84.

111. Zhang X, Castanotto D, Nam S, Horne D, Stein C. 6BIO enhances oligonucleotide activity in cells: a potential 
combinatorial anti-androgen receptor therapy in prostate cancer cells. Mol Ther. 2017;25:79-91.

112. Corrionero A, Minana B, Valcarcel J. Reduced fidelity of branch point recognition and alternative splicing induced by the antitumor drug spliceostatin A. Genes Dev. 2011;25:445-59.

113. Hong DS, Kurzrock R, Naing A, Wheler JJ, Falchook GS, Schiffman JS, et al. A phase I, open-label, single-arm, doseescalation study of E7107, a precursor messenger ribonucleic acid (pre-mRNA) splicesome inhibitor administered intravenously on days 1 and 8 every 21 days to patients with solid tumors. Invest New Drugs. 2014;32:436-44.

114. Gao Y, Trivedi S, Ferris RL, Koide K. Regulation of HPV16 E6 and MCL1 by SF3B1 inhibitor in head and neck cancer cells. Sci Rep. 2014;4:6098.

115. Chung FF, Tan PF, Raja VJ, Tan BS, Lim KH, Kam TS, et al. Jerantinine A induces tumor-specific cell death through modulation of splicing factor $3 \mathrm{~b}$ subunit 1 (SF3B1). Sci Rep. 2017;7:42504.

116. Xargay-Torrent S, Lopez-Guerra M, Rosich L, Montraveta A, Roldan J, Rodriguez V, et al. The splicing modulator sudemycin induces a specific antitumor response and cooperates with ibrutinib in chronic lymphocytic leukemia. Oncotarget. 2015;6:22734-49.

117. Effenberger KA, Anderson DD, Bray WM, Prichard BE, Ma N, Adams MS, et al. Coherence between cellular responses and in vitro splicing inhibition for the anti-tumor drug pladienolide $\mathrm{B}$ and its analogs. J Biol Chem. 2014;289:1938-47.

118. Hasegawa M, Miura T, Kuzuya K, Inoue A, Won Ki S, Horinouchi S, et al. Identification of SAP155 as the target of GEX1A (Herboxidiene), an antitumor natural product. ACS Chem Biol. 2011;6:229-33.

119. O'Brien K, Matlin AJ, Lowell AM, Moore MJ. The biflavonoid isoginkgetin is a general inhibitor of pre-mRNA splicing. J Biol Chem. 2008;283:33147-54.

120. Lu GY, Liu ST, Huang SM, Chang YL, Lin WS. Multiple effects of digoxin on subsets of cancer-associated genes through the alternative splicing pathway. Biochimie. 2014;106:131-9.

121. Dapas M, Kandpal M, Bi Y, Davuluri RV. Comparative evaluation of isoform-level gene expression estimation algorithms for RNA-seq and exon-array platforms. Brief Bioinform. 2017;18:260-9.

122. Liu Y, Gonzalez-Porta M, Santos S, Brazma A, Marioni JC, Aebersold R, et al. Impact of alternative splicing on the human proteome. Cell Rep. 2017;20:1229-41.

123. Tokheim C, Park JW, Xing Y. PrimerSeq: design and visualization of RT-PCR primers for alternative splicing using RNAseq data. Genomics Proteomics Bioinformatics. 2014;12:105-9.

124. Lee K, Cui Y, Lee LP, Irudayaraj J. Quantitative imaging of single mRNA splice variants in living cells. Nat Nanotechnol. 2014;9:474-80. 